\title{
Trichoderma- Foliar Pathogen Interactions
}

\author{
Indu S Sawant
}

Principal Scientist, Plant Pathology, National Research Centre for Grapes (ICAR), Pune, Maharashtra, India

\begin{abstract}
Among the group of ubiquitous soil inhabiting fungi, Trichoderma species are of considerable commercial importance due to their ability to suppress many plant pathogenic fungi. They have been widely studied and employed for management of root and seedling diseases of many crops since decades. In recent years they are also being utilized for minimising diseases of foliar plant parts, especially to supress grey mold caused due to infections of Botrytis cinerea and powdery mildews on a number of crops. They also express potential to control downy mildews and have improved the shelf life of grapes. Out of the eighty-nine species of Trichoderma, a number of species exhibit the bio-control activity. The destruction of host hyphae and protoplasm by the various lytic enzymes and toxic volatile and non-volatile compounds produced by these species are the major mechanism of bio-control; apart from deactivation of pathogen enzymes and induction of systemic resistance in host plants. However, significant differences in antagonistic potential among isolates even from the same species from the same niche is observed; and hence selection of a strain with wide host range and environment adaptability becomes a key issue for sustainable biological control.
\end{abstract}

Keywords: Botrytis cinerea, Colletotrichum gloeosporioides, fungicide, induced systemic resistance, mechanism, Plasmopara viticola, powdery mildew, Trichoderma.

\section{THE GENUS TRICHODERMA}

Trichoderma species are ubiquitous soil inhabiting fungi and are the anamorph stage of the genus Hypocrea. They are classified under the fungal division Ascomycota; order, Hypocreales; family, Hypocreaceae; genus, Trichoderma. Eighty-nine species of Trichoderma have been named based on molecular phylogenetic analyses [1]. Trichoderma species have the ability to suppress fungi belonging to many other genera, including some of those which are pathogenic to crop plants. This unique ability of Trichoderma is due to the production of extracellular lytic enzymes, non-volatile and volatile toxic metabolites, high competitive saprophytic ability, high proliferation rate, etc. as well as induction of systemic resistance in host plants. They are also the most studied and exploited group of biocontrol agents as they are present in most of the soils worldwide, easy to isolate, identify, multiply (Figs. 1 to 6) and considered safe for plants and animals. Though Trichoderma spp. are used mainly as soil inoculants for the control of root diseases, their ability to control some of the foliar diseases like gray mold, powdery mildews and postharvest decays on different crop species are also well documented.

\section{THE FOLIAR ENVIRONMENT}

Unlike the rhizosphere, which is buffered in the biological, chemical and physical soil environment, the phyllosphere and the fructosphere are exposed to the harsh gaseous atmosphere and faces sharp fluctuations in temperature and surface wetness, vapour water pressure

*Address correspondence to this author at the Principal Scientist, Plant Pathology, National Research Centre for Grapes (ICAR), Pune, Maharashtra, India; Tel: +91-20-2695-6031; Fax: +91-20-2695-6099;

E-mail: indulika18@yahoo.co.in deficit, gases, air pollutants, wind, radiation, etc. This makes the foliar environment very different from the soil environment and the epiphytic microbial populations differ substantially from the rhizosphere populations. The rhizosphere is highly suitable for proliferation and activities of diverse microfloral species comprises of bacteria, filamentous fungi, actinomycetes, protozoa and algae. In contrast, the phyllosphere is colonised predominantly by bacteria and then yeasts, while the filamentous fungal species may be present mainly as spores [2]. These populations keep changing as a result of fluctuations in the physical, chemical and nutritional environment of the phyllosphere.

The phyllosphere is, thus, considered a difficult site for biological control as the applied biocontrol agent should be able to establish, proliferate and retain its antagonistic potential in the harsher and frequently fluctuating foliar environment. These environmental effects are minimized in the controlled conditions of poly houses and many studies on biological control of fruit and leaf diseases have focused in polyhouse grown crops. However, research has shown that it is possible to achieve a significant level of biological control in field, too, as in the case of gray mold of grapes in vineyards. In this article an attempt has been made to review the work on the interactions of Trichoderma with foliar pathogens.

\section{CONTROL OF FOLIAR DISEASES BY TRICHODERMA}

\subsection{Botrytis Blight or Gray Mold Disease}

Gray mold is caused by the ubiquitous, necrotrophic fungus Botrytis cinerea. It attacks leaves, flowers and fruits 


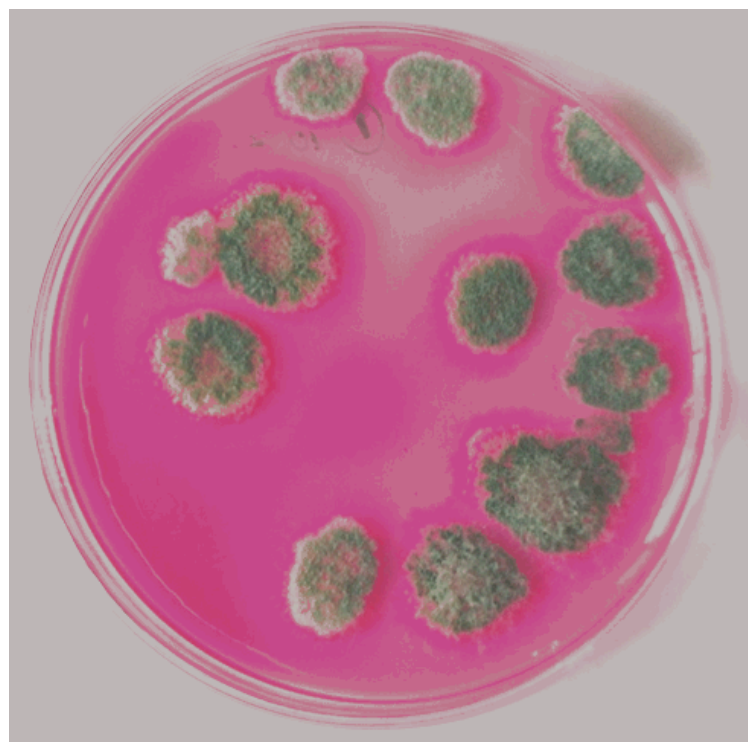

Fig. (1). Trichoderma colonies growing on semi-selective medium.

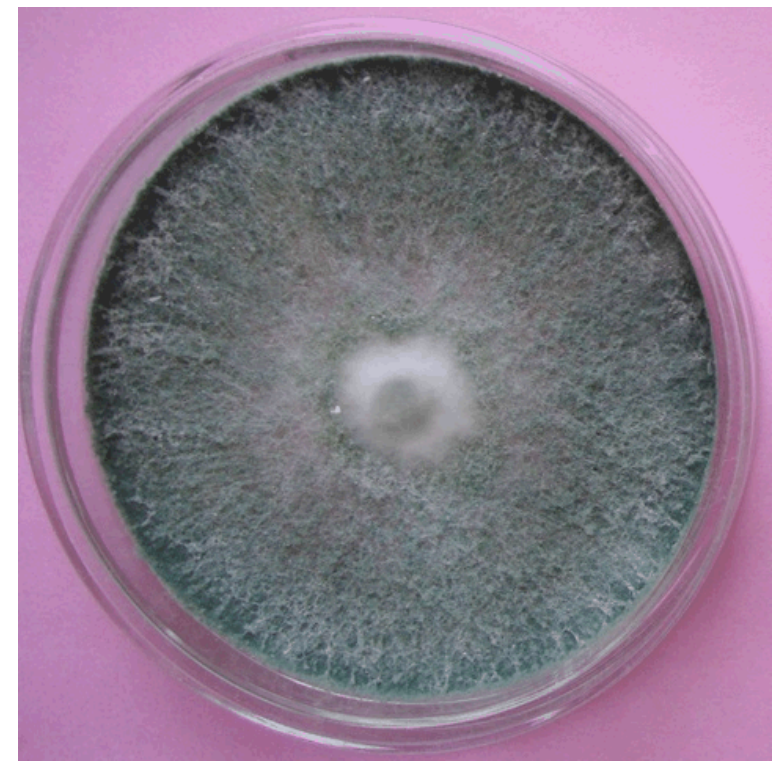

Fig. (2). Trichoderma growth on potato dextrose agar medium.

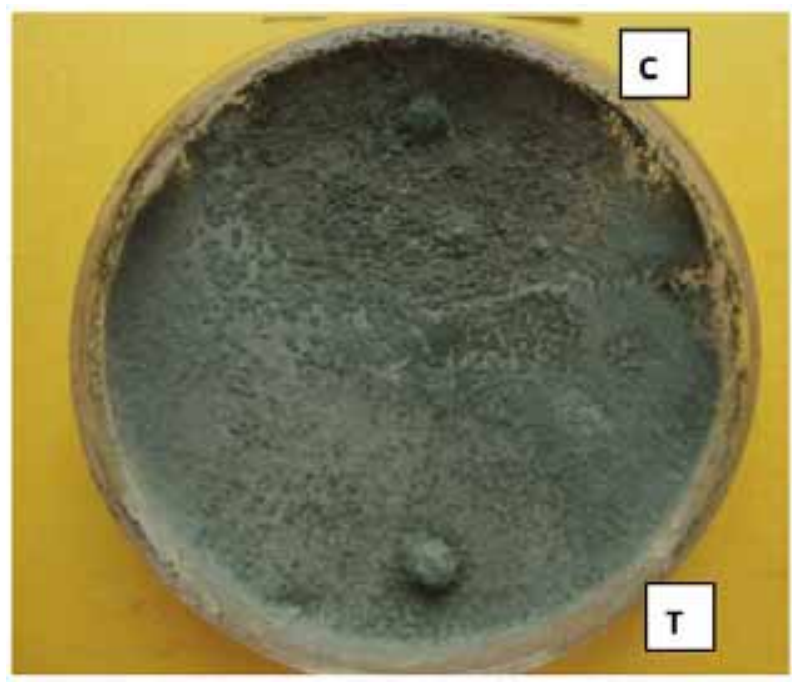

Fig. (3). T. koningii (T) overgrowing on Colletotrichum gloeosporioides (C) colony. 


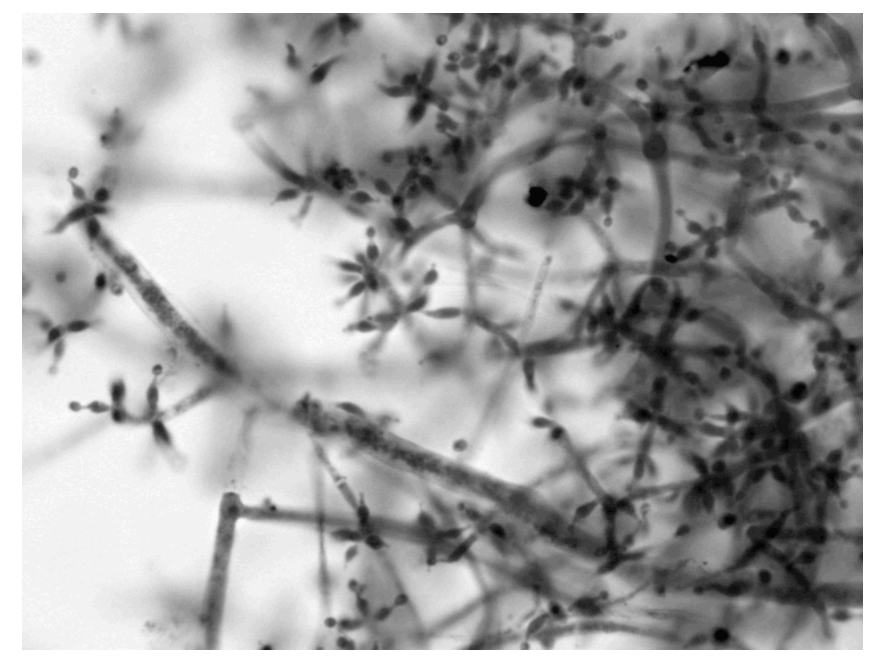

Fig. (4). Phialids and conidia of T. koningi.

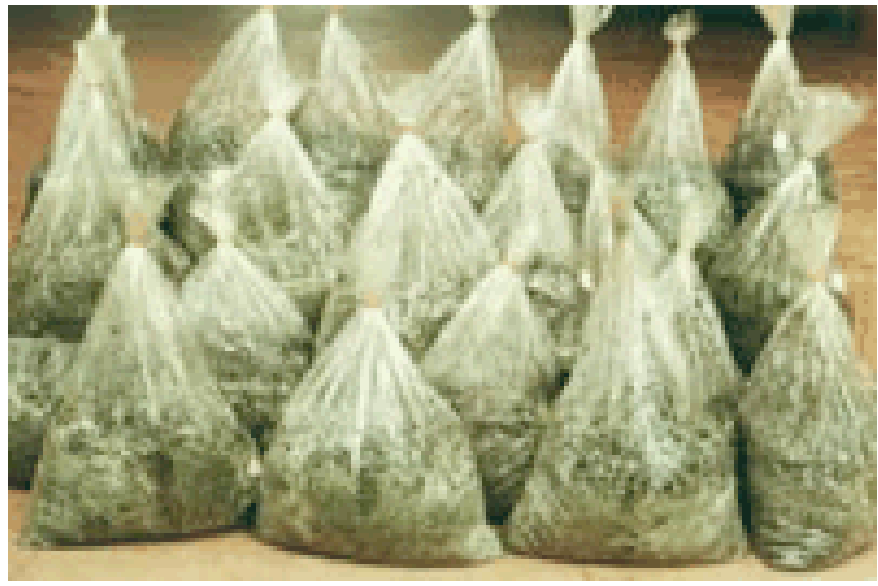

Fig. (5). Multiplication of Trichoderma on composted sterilized coffee husk in pp bags.

The photo used in Fig. (5) is by the same author which was used in a symposium poster presented in National symposium on Horticultural Biotechnology, Bangalore, 28-30th October 1996.

The title of the poster was: Sawant, Indu S. and S.D. Sawant. 1996. Commercial production of T. harzianum on coffee wastes- prospects and problems.

New Agriculturist: http://www.new-ag.info/en/focus/focusItem.php?a=1178

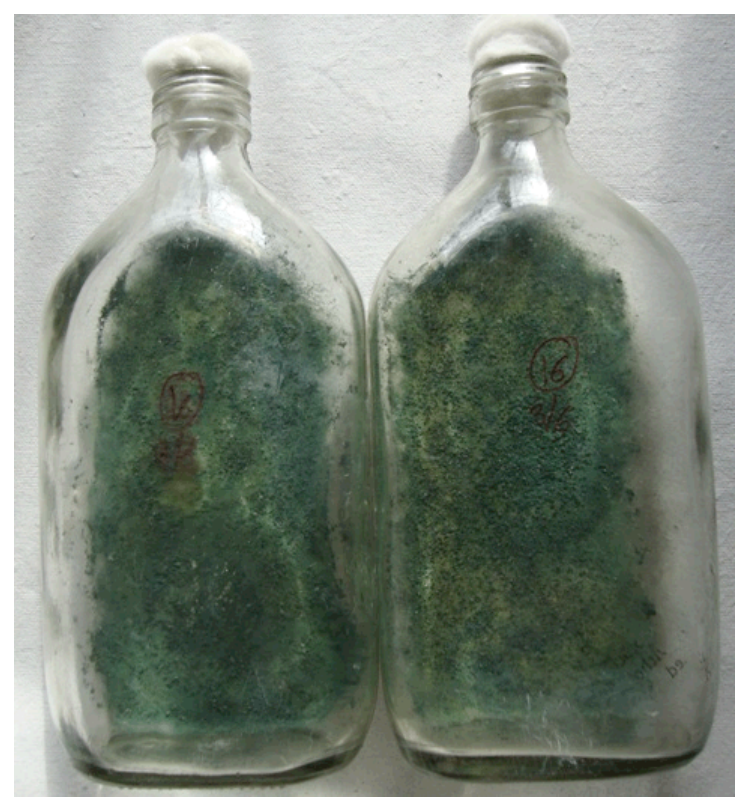

Fig. (6). Multiplication of Trichoderma on potato dextrose broth in used brandy bottles. 
of many field and poly house grown crops like grape, strawberry, tomato, cucumber, beans, onion, rose, gerbera, begonia, carnation, chrysanthemum, geranium, marigold, petunia, etc. Among the different species and isolates of Trichoderma evaluated worldwide for control of foliar diseases, one of the successful examples is of T. harzianum Rifai strain T39, which was initially selected and commercialized for the control of Botrytis diseases [3]. T. harzianum strain T39, was isolated from the natural surface microflora of cucumber fruit [4]. It is thought that this strain acts by competing with the pathogen for nutrients and space on the plant surface and thus inhibits its pathogenicity process. Subsequent studies have shown that it also induces local and systemic resistance in plants, and suppresses enzymes involved in pathogenesis. The commercial product is available under the name Trichodex WP (Makhteshim Chemical Works) containing fungal mycelium and conidia at minimum $1 \times 10^{9}$ per gram cfu (colony forming units) of T39 isolate [5]. The product has been tested successfully on various crops for control of grey mold, powdery mildew, leaf spots etc.

Probably the most extensive evaluation of the T. harzianum T39 formulation was done for control of grey mold disease of grapes. The product was evaluated under diverse commercial conditions in one hundred and thirty three field studies conducted on thirty four grape cultivars in nineteen countries over a seven year period [6]. Overall results showed that T39 could provide $36.3 \%$ control of grey mold as compared to $52.3 \%$ control obtained by chemical treatments [6]. Trichoderma could establish well on grape berries as seen by the high populations of $4.5 \times 10^{5} \mathrm{cfu}$ per berry on treated grapes as compared to 400 to 2000 on untreated grapes [7]. As Botrytis mainly infects grapes during flowering and then remains as latent infection till near veraison; five Trichoderma applications throughout bloom and fruit development or two late season applications were sufficient to control the disease [8]. It was also possible to minimize the overwintering inoculum of $B$. cinerea by late season spray applications of selected cold tolerant strains of Trichoderma species [9].

Trichoderma has also been used for the biocontrol of Botrytis cinerea on strawberries [10, 11]. However as strawberry flowering is a continuous process, frequent applications of T39 at 2 day intervals were needed which was not economical. A novel method of dissemination of Trichoderma to strawberry flowers was devised utilizing bees which regularly visit the strawberry flowers for collection of pollen. The Trichoderma spores were kept near the exit passage in the bee boxes in such a way that the legs and other body parts of the bees get dusted by the spores [12, 13]. Each bee carried about $1 \times 10^{5} \mathrm{cfu}$ of $T$. harzianum on its body parts of which about half were carried on its legs; which got deposited on the strawberry flowers when the bees visited them for collection of nectar. This method of delivery deposited less number of cfus on the flowers than when T. harzianum was applied as spray, but it resulted in better disease control. These plots yielded more than even those plots which were treated with fungicides. The bees could effectively disseminate $T$. harzianum upto a distance of
$200 \mathrm{~m}$ [13]. Similarly, T. harzianum T39 (Trichodex) at 0.2 $\mathrm{g}$ per 1 could also effectively control gray mold in greenhouse grown tomato and cucumber [14].

These studies have brought out the commercial feasibility of biological control of grey mold, with Trichoderma applications alone or in alternation with fungicide applications. This method would considerably minimize the use of chemical fungicides in fruits and may help to increase food safety.

\subsection{Powdery Mildews}

In cucumber, T. harzianum T39 (25\% powder of Trichodex) at $0.2 \%$ concentration applied as foliar spray or as soil drench as a 100-ml dose in a 101 container, could provide effective control of powdery mildew [15]. The disease control was better when the preparation was applied as soil drench than as spray, indicating that T39 induces systemic resistance in cucumber against powdery mildew apart from direct parasitism or antimicrobial action on the pathogen. The authors showed that the biocontrol agent gave more than $75 \%$ to almost cent percent disease control on young leaves but its biocontrol efficacy declined as the leaves grew older indicating that the age of the leaf has an impact on disease control efficacy of T39. Further, the control was more effective under low disease pressure conditions as compared to under high disease pressure conditions. Studies have also indicated that epiphytic Trichoderma spp. isolated from dogwood plants growing in wild, where the incidence of the disease was low, had the ability to reduce the severity of powdery mildew on dogwood under pot test conditions [16]. In another study it was shown that different species of Trichoderma viz. T. viride, T. harzianum, T. hamatum, T. longiforum and $T$. koningi could effectively control powdery mildew on cluster bean [17].

The ability of culture filtrates of $T$. harzianum and $T$. viride to control powdery mildew disease in mulberry by more than $60 \%$, on par to that provided by carbendazim, was shown to be due to its ability to inhibit conidial germination of the pathogen Phyllactinia corylea by almost 50\% [18]. In squash also application of culture filtrates of $T$. viride and T. harzianum, either alone or mixed with fungicide in equal proportions, could provide more than $60 \%$ control of powdery mildew under field conditions in two year trials [19]. The disease control provided by the mixture was also significantly higher than that obtained when the fungicide was used alone.

These studies indicate to the possibility of inducing the defense mechanism of the plants against powdery mildew disease by soil application of efficient strains of Trichoderma and of further control of the disease by foliar applications, which should be sufficiently effective under low disease pressure conditions. When the disease pressures are high and if the disease is not controlled by the above biocontrol method, the Trichoderma sprays can be alternated with or used in combination with safe fungicides disease, as practiced for grey mold control. 


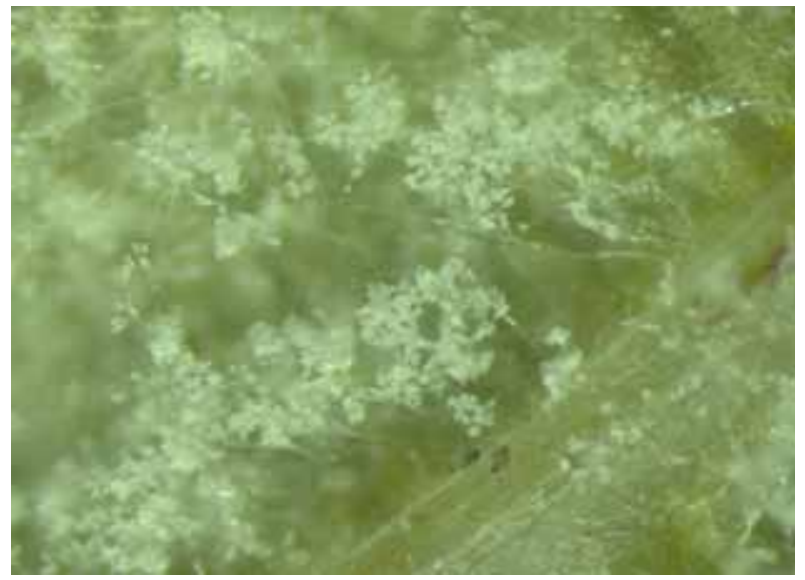

Fig. (7). Abundant sporangial growth of $P$. viticola on naturally infected grape leaves.

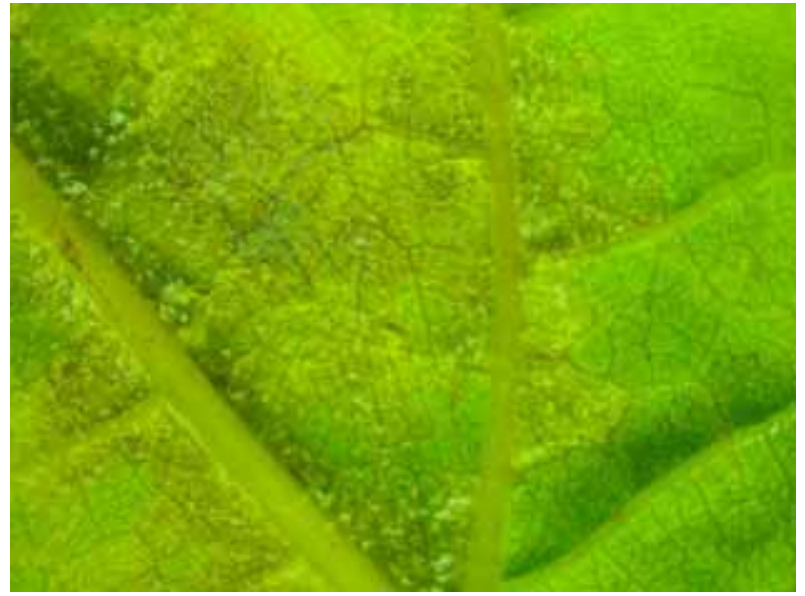

Fig. (8). Suppression of sporangial growth of $P$. viticola by Trichoderma.

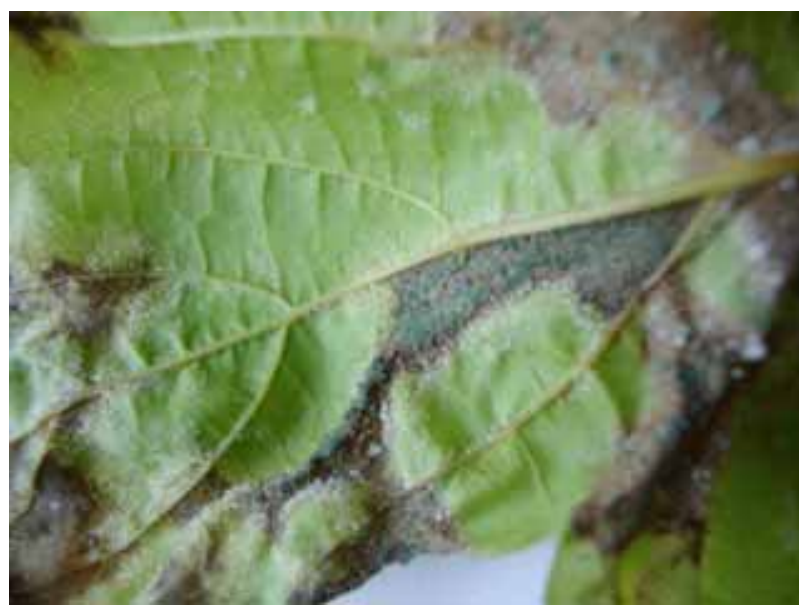

Fig. (9). Colonisation of necrotic leaf areas by Trichoderma.

\subsection{Downy Mildew}

Two to three preventive sprays of $T$. harzianum T39 could also protect grapevines against downy mildew infections in a greenhouse [20]. The antagonist did not inhibit sporangial germination or parasitize $P$. viticola, the pathogen of downy mildew. But when T39 was selectively applied on few leaves or on leaves on one side of the plant, the treated as well as the untreated leaves showed resistance to the disease, indicating that T39 acts by eliciting an induced systemic reaction in grapevines against downy mildew as was observed in cucumber against powdery mildew disease [15]. Transcriptional analysis revealed that T39 influenced the expression of genes involved in recognition of the pathogen as well as those which regulate/trigger the plant defense mechanisms [21].

In ongoing studies at this Centre, it was observed that Trichoderma species could suppress growth of Plasmopara viticola and Erysiphe necator on naturally infected grape leaves (Figs. 7-9) (Sawant et al., unpublished data). Grape downy mildew pathogen $P$. viticola infects grapevines 


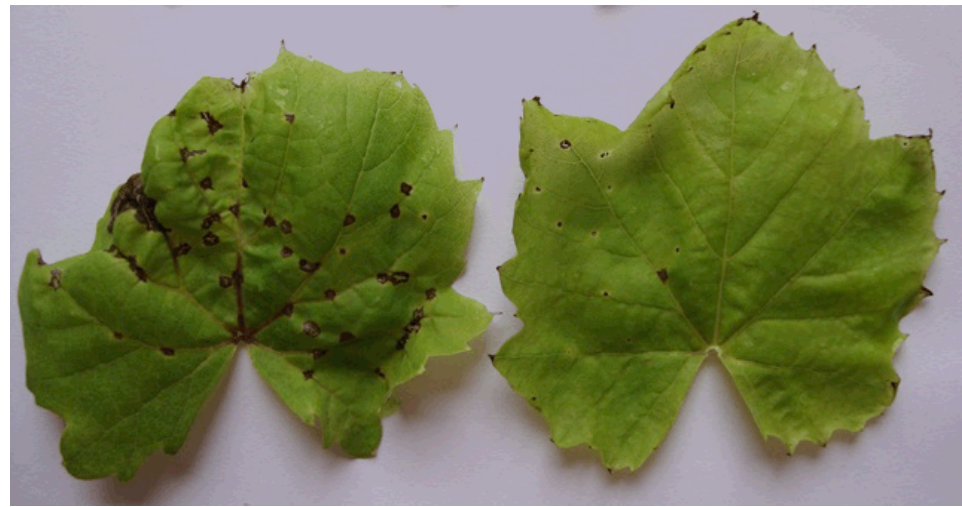

Fig. (10). Reduction of anthracnose infection on grape leaves by Trichoderma. Treated leaf (right) and untreated control (left).

through the stomata and post-infection the sporangiophores also emerge though the stomata. In grapevine leaves, the stomata are present only on the lower (abaxial) leaf surface, thus the fungicide applications, especially those with contact action alone are not very effective as the sprays do not completely cover the entire lower leaf surface. On the other hand Trichoderma can grow and proliferate on healthy leaf surfaces, and it sporulates profusely on the downy mildew infected chlorotic/necrotic leaf areas. These spores will be easily dispersed by air currents and rain water to the inner canopy, too, and provide protection to that part of the foliage which could not be covered by the fungicide spray.

Further studies are required to identify Trichoderma isolates which will be capable of eliciting an ISR effect in grapevines against downy mildew as well as directly inhibiting or parasitizing the pathogen. Such antagonistic Trichoderma isolates may also be used in integration with safer fungicides to enhance the disease control in vineyards.

\subsection{Anthracnose}

Antagonism and parasitism of many Colletotrichum species by different species of Trichoderma and their potential use for biological control of anthracnose disease is reported in various crops [22, 23] including potential for control of C. gloeosporioides on brambutan [24] and grapes [25]. Trichoderma species could also control anthracnose infections on grapevine foliage (Fig. 10) caused by C. gloeosporioides in vineyard [26].

\subsection{Other Foliar Diseases}

In tomato, T. harzianum T39 could effectively control leaf mold (Cladosporium fulvum) in tomato and white mold (Sclerotinia sclerotiorum) in cucumber growing in greenhouses [14]. Postharvest treatment with T. harzianum ( $\mathrm{TrH} 40$ ) could control stem end rot, anthracnose and brown spot of rambutan fruits [24]. Further, the colour and postharvest quality of the fruits was better in the T. harzianum treated fruits. Control of Phytophthora induced black pod disease of cocoa was achieved by fortnightly sprays of T. asperellum isolated from soil [27]. Interestingly, isolates which provided better disease control in the beginning of the season were not so effective at the end of the season and vice versa. Cladosporium herbarum which is responsible for causing verrucose of passion fruit could be parasitized by T. harzianum, T. viride and T. koningii [28]. These isolates also produced toxic volatile and non-volatile metabolites as well as cellulose, pectinase and amylase enzymes.

\subsection{Postharvest Diseases}

Pre-harvest spray application of $T$. harzianum 5R was found effective for management of postharvest decay in table grapes. Two sprays at $5 \times 10^{6}$ spores $/ \mathrm{ml}$ applied at 20 and 2 days before harvest could prevent postharvest decay in grapes stored for short durations at ambient temperatures [29]. There was less decay in $T$. harzianum $5 \mathrm{R}$ treated grapes than in non-treated grapes which were stored with or without sodium metabisulphite (available commercially as grape guard sheets, which are a source of in-package sulphur dioxide generation) (Fig. 11). Furthermore, grapes treated with $T$. harzianum $5 \mathrm{R}$ retained their freshness for longer duration as compared to non-treated grapes.

Similarly, the shelf-life of table grapes which were stored for long duration at low temperature was enhanced by two pre-harvest sprays of $T$. harzianum $5 \mathrm{R}$ at $1 \times 10^{6}$ spores $/ \mathrm{ml}$ [30]. The grapes treated with $5 \mathrm{R}$ could be safely packed with a lower than recommended dose of sodium metabisulphite per box without fear of increased decay associated with the lower dose of the generator sheet. Further, in these grapes the sulphur-dioxide injury observed at the recommended dose of the sheet was also not seen. The mechanism by which $T$. harzianum $5 \mathrm{R}$ could delay the browning of rachis and pedicles and maintain berry freshness (Fig. 12) enhancing the shelf life needs to be studied.

An antagonistic isolate of $T$. harzianum $(\mathrm{TrH} 40)$ isolated from rambutan orchards could effectively reduce the severity of postharvest stem end rot, anthracnose and brown spots caused by Botryodiplodia theobromae and Colletotrichum gloeosporioides in this crop [31]. Similarly, an antagonistic T. asperellum isolate was identified for control of black rot disease in pineapples caused by Thielaviopsis paradoxa [32].

In another study, it was shown that the shelf-life of various kinds of fresh fruits is reduced due to postharvest decay caused by fungal pathogens like Rhizopus stolonifer, Botrytis cinerea, and Penicillium expansum and postharvest treatment with a $T$. harzianum formulation could minimize the decay and enhance the shelf-life [33]. 


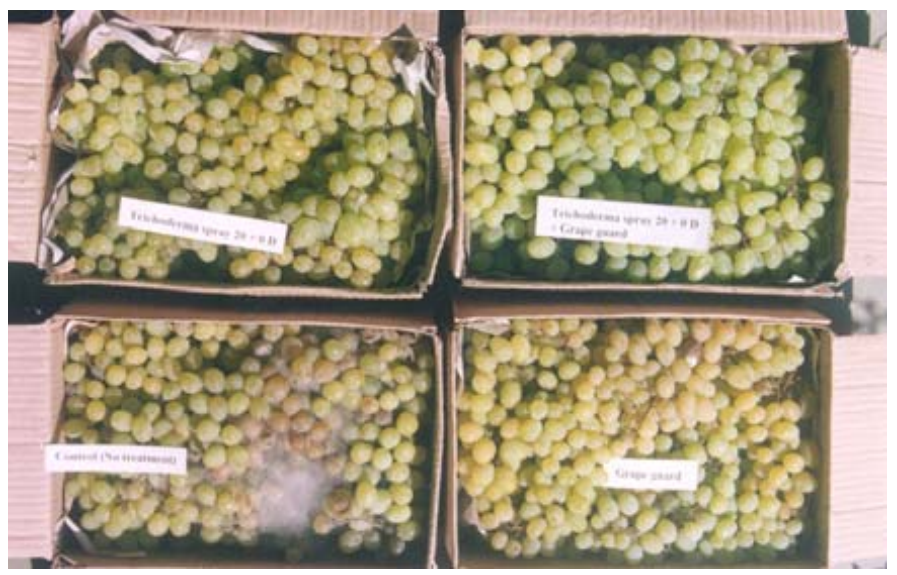

Fig. (11). Control of postharvest decay by Trichoderma in grapes stored for short duration at ambient temperatures. The photo used in Fig. (11) is by the same author which was used in the following book chapter.

Sawant, S. D. and Sawant, Indu S. 2003. Enhancement in shelf life and quality of grapes by effective management of plant diseases and other cultural practices - success story of Maharashtra. In. Singh D.P (Ed.) Implications of Plant Diseases on Produce Quality. Kalyani Pubishers, Ludhiana. pp. 33-41 (198p).

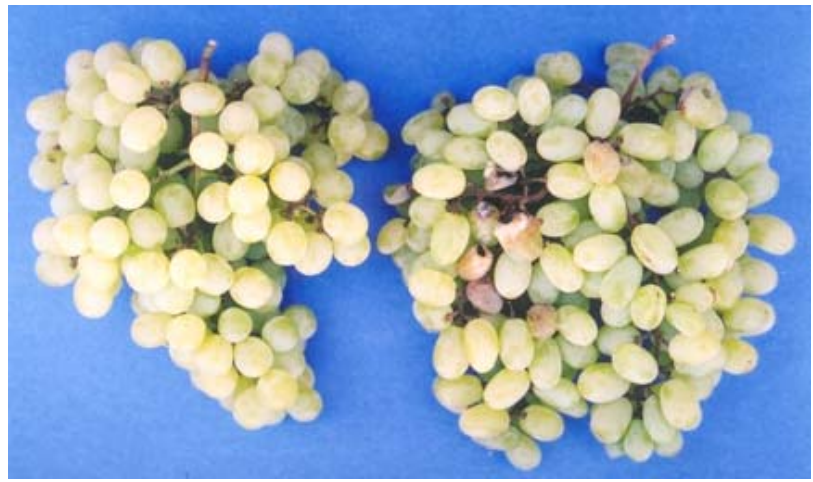

Fig. (12). Control of postharvest decay by Trichoderma in grapes stored for long duration at zero degree temperature.

The photo used in Fig. (12) is by the same author which was used in:

"4.1 Mass multiplication of Trichoderma harzianum 5R. In. Commercialiazation of Horticultural Technologies. ICAR, Krishi Bhavan, New Delhi. p. 36.

\subsection{Improved Plant Growth}

Trichoderma species also have beneficial effects on plants. Application of T. hamatum 382 (T382) to potting mixture increased plant vigour of both susceptible and highly susceptible cultivars of rhododendron, even though it did not suppress Phytophthora die-back in the highly susceptible cultivars [34].

\section{MECHANISM OF BIOCONTROL}

The mechanisms involved in biocontrol of foliar pathogens by Trichoderma species are the same as those involved in the control of root pathogens i.e. mycoparasitism, antibiosis and competition for space and nutrients, induction of systemic resistance, etc. It is possible that more than one mechanism is involved in a hostantagonist-pathogen interaction. For example, the suppression of gray mold by $T$. harzianum T39 was related to the competition of resources, inhibition of enzymes involved in pathogenesis, and induced systemic resistance [35], but antibiosis and mycoparasitism were not involved in the biocontrol process.

\subsection{Mycoparasitism}

Species of Trichoderma produce a number of enzymes which hydrolyse the polysaccharides, cellulose, $\beta$-glucans and chitin present in the cell walls of the plant pathogenic fungi [36] and aid the mycoparasitise to penetrate the cells. These enzymes include both endo- and exo-chitinases which are effective against the fungi containing chitin in their cell walls. Most of these enzymes are induced in the presence of substrates. Further, the levels of enzymes viz. chitinase, $\mathrm{N}$-acetylglucosaminidase, $\quad \beta$-1,3-glucanase, protease, cellulose, endoglucanase, glucosidase, amylase were shown to be increased in presence of substrates [37]. T. harzianum isolate 1051 produced a novel protease which was biologically active against Crinipellis perniciosa, the causal agent of witches' broom [38].

\subsection{Antimicrobial Chemicals}

Trichoderma species are producers of various volatile and non-volatile antimicrobial compounds which are active against a range of microorganisms [39]. Though the inhibitory effect against many root pathogens is well 
documented, there are a few reports on their effect on foliar pathogens. The volatile metabolites produced by isolates of $T$. harzianum, $T$. virens, $T$. viride, $T$. reesei and T. saturnisporum were inhibitory to Colletotrichum capsici [40, 41]. In another study, all thirty four Trichoderma isolates produced volatile metabolites which were toxic to C. gloeosporioide [26]. These isolates belonged to seven Trichoderma species viz. T. harzianum, $T$. viride, T. koningii, T. pseudokoningii, T. hamatum, T. asperellum and $T$. lectea and were collected from different geographical locations of India.

\subsection{Suppression of Enzymes Produced by the Pathogen}

Some isolates of Trichoderma, including $T$. harzianum T39 have the ability to deactivate or minimize the activities of enzymes involved in pathogenesis by $B$. cinerea viz. endo-and exo-polygalacturonases, pectin methyl esterase, pectate lyase, and cutin esterase, etc [42-44]. However, it had no effect on the production of carboxymethyl esterase and carboxymethyl cellulose [42-44] by breaking them into peptide chains or constituent amino acids.

A T. harzianum isolate could also reduce the secretion of endo-polygalacturonase by Alternaria alternata [45]. Interestingly, the authors observed that the secretion of the enzyme was also slightly inhibited in the presence of $\mathrm{GA}_{3}$, IAA or BAP bio-regulators.

\subsection{Supression of Sporulation or Conidial Germination of Pathogen}

Trichoderma spp. produce chitinolytic enzymes which may inhibit the infection process at pre-infection stage, e.g. endochitinase and chitobiosidase inhibited the spore germination and germ tube elongation of fungi which contain chitin in their cell wall, viz. Uncinula necator, Botrytis cinerea, Ustilago avenae, Fusarium solani, but did not inhibit sporangial germination of Pythium ultimum, which has no chitin in its walls [46]. Similarly, a low level of inhibition in spore germination was observed in fungi which contain a low level of chitin in their cell walls such as the yeast Saccharomyces cerevisiae. Isolates of Trichoderma and Gliocladium can also suppress sporulation of B. cinerea on strawberry [47] and would help in reducing inoculum load.

\subsection{Induced Systemic Resistance}

Trichoderma isolates are also known to induce systemic resistance (ISR) in plants against fungal diseases. Apart from parasitism, T. harzianum T39 was also shown to be an elicitor of systemic resistance in plants as soil applications of live spores in the root zone or even the application of dead cells could provide reduction in foliar diseases including powdery mildew [35]. Further, even dead cells of T. harzianum T39 were partially effective in controlling gray mold disease. However, in grape leaves only the spray application of $T$. harzianum T39 elicited a lateral and acropetal induced systemic reaction against $P$. viticola and root drenching was ineffective in inducing systemic resistance [20]. The authors had observed the ISR effects on the leaves present on the same shoot as those where the treatments were applied, but had not studied as the effects on leaves present on other shoots of the grapevine. The response decreased as the interval between application of Trichoderma and the pathogen challenge was increased.

They further observed that treatment with $T$. harzianum T39 increased the expression of defense-related genes [48] which induced resistance in the plants. However, this effect was more pronounced in tissues closer to the site of antagonist application than in tissues which were distant, and this was reflected in a higher disease control near the site of application as compared sites which were distant. Interestingly, priming of defense gene expression was greater in plants treated with T. harzianum T39 than in those plants which were treated with the chemical ISR inducer, benzothiadiazole. Further, benzothiadiazole adversely affected the grapevine vegetative growth parameters and also chlorophyll content; while no such adverse effects were seen in plants treated with T39. In contrast to the activation of salicylic acid plant defense pathway by the chemical inducer, T39 induced the jasmonic acid plant defense pathway.

Addition of conidia of T. hamatum 382 (T382) in the form of dry powder to the potting mixture to a final count of $2 \times 10^{5}$ cfu per $g$ dry weight of the mixture, minimized the Botrytis infections on greenhouse grown begonia plants [49]. The reduction in blight severity in T382 treatment was at par to the reduction observed in plants treated with chlorothalonil at weekly intervals. Further, the vegetative growth and over all marketability of T382 inoculated plants was higher as compared to the uninoculated control or chlorothalonil treaed plants. Some other studies suggest that the ISR effect is more apparent in compost amended medium, probably it supports proliferation of the introduced organism; and in cultivars which are not highly susceptible to the disease [34], even though it may induce other effects like enhanced plant vigour in the highly susceptible cultivar, too.

Further, Phytophthora infections in roots and crowns of cucumber were significantly reduced by adding T382 into the potting mixture [50]. The ISR is attributed to an increase in the activities of the defense enzymes, peroxidase and chitinase in the leaves of cucumber [51].

\subsection{Competition for Resources}

T. harzianum T39 suppression of gray mold was proposed to be due to the antagonist competing with the pathogen for resources which resulted in delayed germination of conidia and subsequent growth of the germ tube. Furthermore, timely application of Trichoderma allowed it to colonize the senescing floral tissues before Botrytis and helped to reduce infections [52]. One of the successful examples of biological control in above ground plant parts is the control of silver leaf disease by application of Trichoderma to the pruning wounds through pruning shears [53] which are able to parasitize the tissues before the pathogen can attack. 

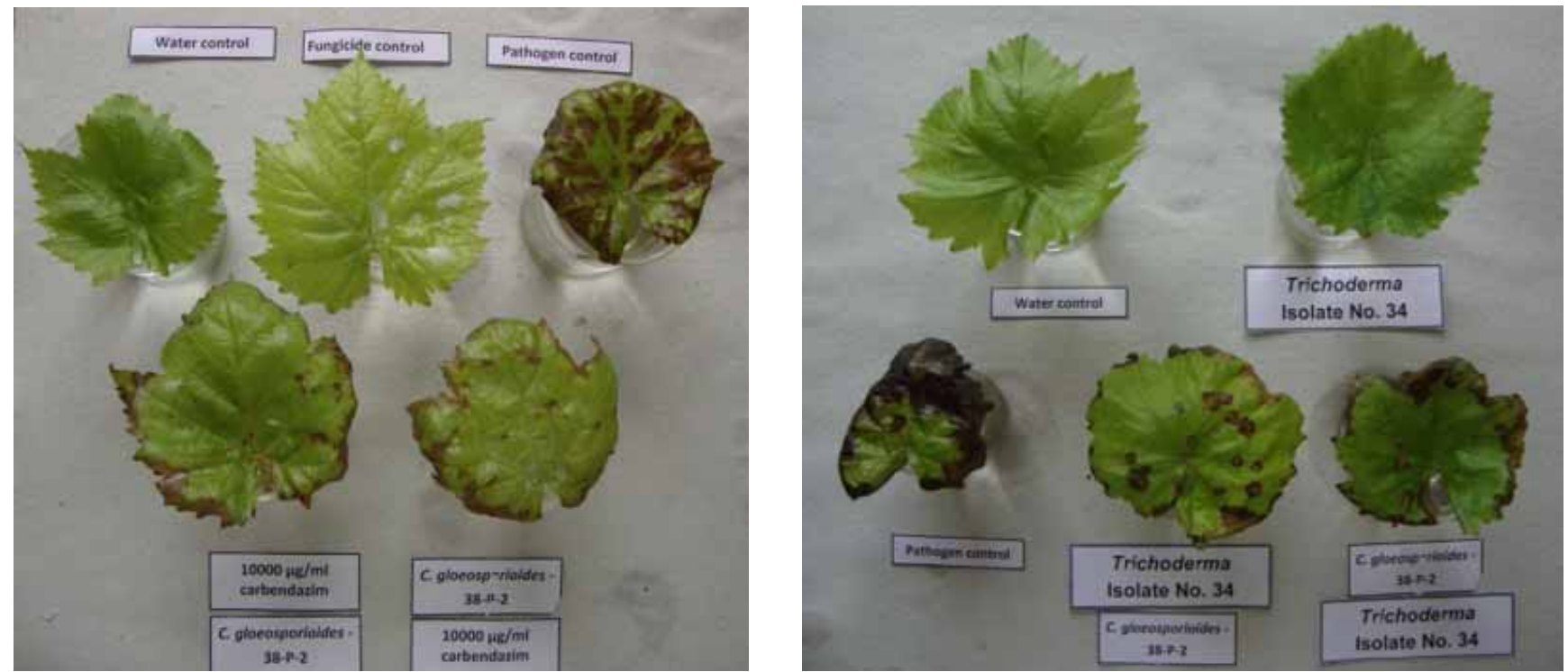

Fig. (13). Efficacy of T. harzianum 5R in controlling anthracnose infection caused by carbendazim resistant strain of $C$. gloeosporioides on leaves first treated with the fungicide/5R and then inoculated with the pathogen $(\mathrm{L})$; or first inoculated with the pathogen and then treated with the fungicide/5R (R).

\section{INTEGRATION WITH FUNGICIDES}

\section{i. For Management of Diseases}

T. harzianum could safely be used in alternation with diethofencarb plus carbendazim, or as tank mix with iprodione in the table and wine grape vineyards providing 64-68\% reduction in postharvest rot caused by Botrytis cinerea [7]. Trichoderma applications could be used effectively to substitute few fungicide applications, or it could be used with half-rates of iprodione, thus decreasing overall fungicide use in vineyards [8].

The chitinolytic and glucanolytic enzymes produced by Trichoderma harzianum enhanced the antifungal properties of fungitoxic compounds viz. gliotoxin, flusilazole, miconazole, captan and benomyl as evident by Botrytis cinerea spore germination bioassay [54]. The enhancement was synergistic as the $\mathrm{EC}_{50}$ of the mixtures were much lower than that of the enzymes or the fungitoxic compounds alone. As would be expected, the level of synergism appeared to be higher when the enzymes were combined with compounds acting on the membrane structure as compared with those compounds having multiple or cytoplasmic sites of action.

\section{ii. For Management of Fungicide Resistant Strains of Pathogens}

A $T$. harzianum isolate could parasitize carbendazim resistant isolates of $C$. gloeosporioides and could suppress development of symptoms in artificially inoculated Thompson Seedless leaves [55]. The supression was on par to that obtained by application of $10000 \mathrm{ppm}$ carbendazim (Fig. 13). Integration of efficient isolates of Trichoderma in an IPM programme may prove useful in management of fungicide resistant strains of pathogens.

\section{ESTABLISHMENT - POST INOCULATION}

The establishment and proliferation of Trichoderma on foliage will vary according to the plant species, prevailing environmental condition and the Trichoderma isolate. The populations will also be affected by the age of the leaves and nutrient status of the plants [56]. Other factors which may affect the populations are interactions of Trichoderma with the dominant leaf micro-flora, the type of formulation used and other agricultural interventions. The proliferation of the introduced Trichoderma spp. on the phyllosphere results in a change in the biological equilibrium existing on the plant surfaces due to competition for nutrients or space. This competition results in an increase or decrease in the natural populations of bacteria, yeasts and filamentous fungi, preexisting on the phylloplane [57] and would affect the survival of the introduced Trichoderma spp. Temperature and RH requirements of the particular Trichoderma isolate would also affect its survival. Fungicide residues on leaves also affect the survival and proliferation of Trichoderma isolates (Sawant et al., unpublished data).

Thus, different post-application population dynamics on leaf and fruits have been reported by different workers. The populations of $T$. harzianum on grapes treated at 0.5 to $1.0 \mathrm{~g} / 1$ were $4.5 \times 10^{5}$ per grape berry compared with 400 2000 per berry on untreated bunches [7]. Under the tropical climate of India, two foliar applications of an aqueous suspension of $T$. harzianum $5 \mathrm{R}$ containing $1 \times 10^{6}$ spores $/ \mathrm{ml}$ applied at 20 and 2 days before harvest on grapes, resulted in about $120 \mathrm{cfu} /$ berry [30]. When the same isolate was applied on grape foliage as an aqueous suspension containing $5 \times 10^{6}$ spores $/ \mathrm{ml}$, the initial counts were about $1 \times 10^{5}$ per $\mathrm{cm}^{2}$, which reduced to $4000 \mathrm{cfu}$ per $\mathrm{cm}^{2}$ after 5 days of application and further to $260 \mathrm{cfu}$ per $\mathrm{cm}^{2}$ after 15 days of application [26]. In an interesting study on survival of four Trichoderma 


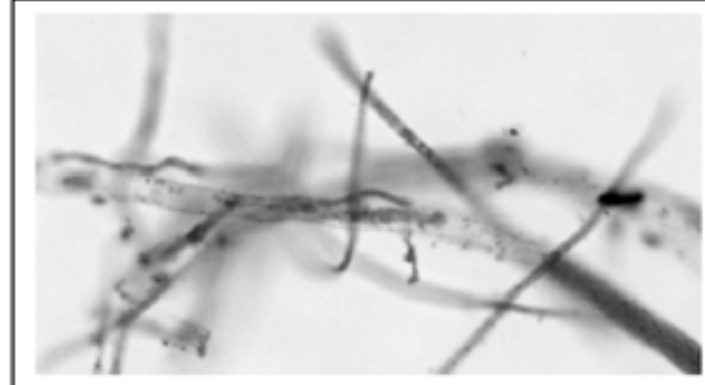

\section{T. harzianum NAIMCC-1727}

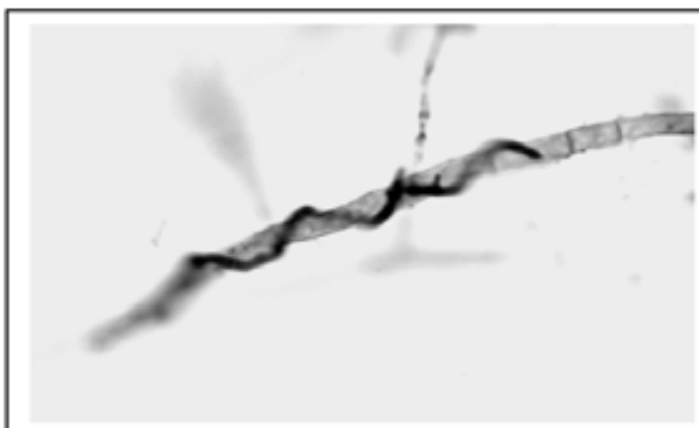

T. viride NAIMCC- 1817

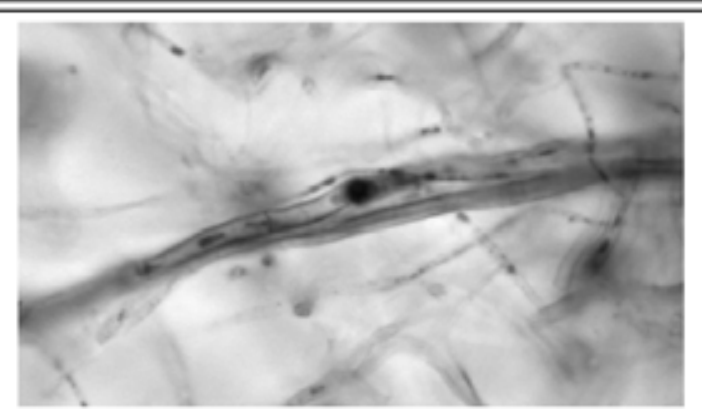

T. pseudokoningii NAIMCC-1775

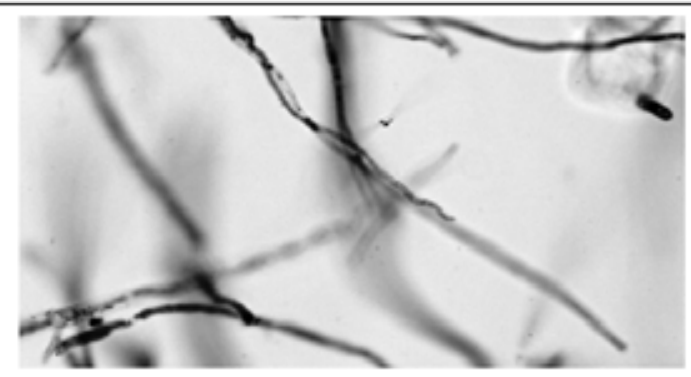

T. asperellum NAIMCC-1763

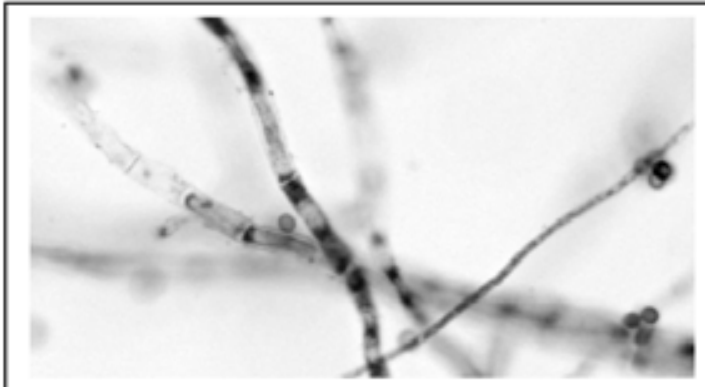

NRCG-T. harzianum 5R

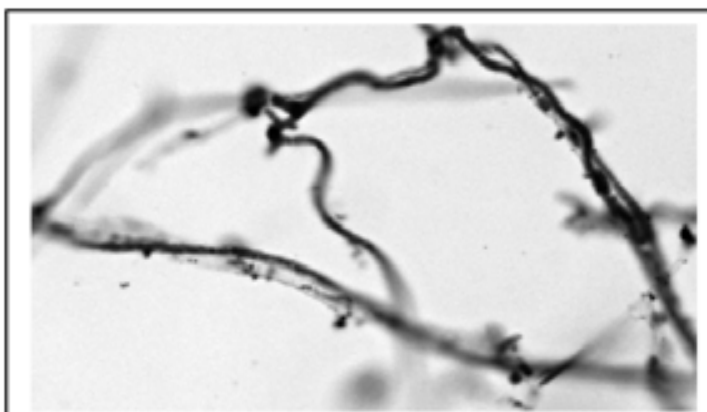

T. koningii (NAIMCC-1760)

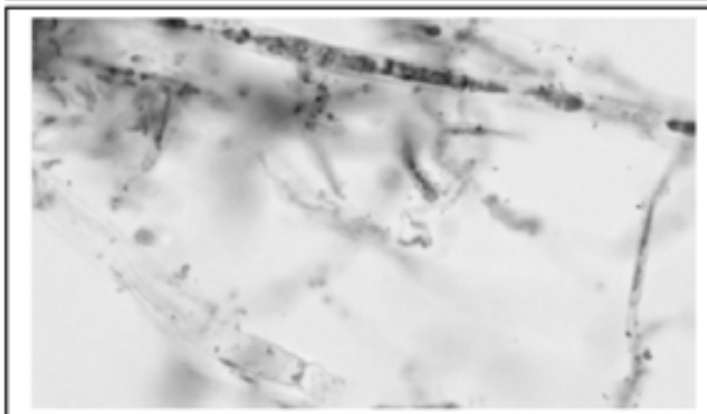

T. hamatum NAIMCC-1719

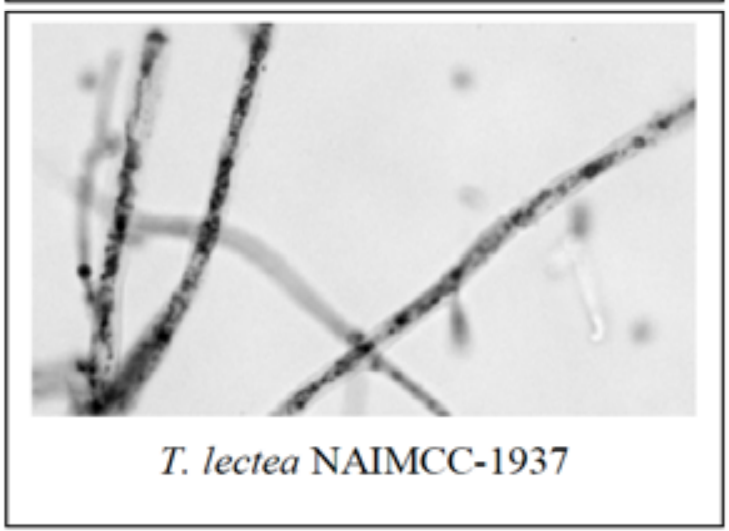

Fig. (14). Parasitism of Colletotrichum gloeosporioides by different species of Trichoderma.

isolates with different biological properties against two pathogens of strawberry, it was shown that the isolate which could parasitize both $C$. acutatum and B. cinerea had better survival than others which either did not mycoparasitise or parasitized only one of the isolates [58]. However, instead of a mix, when they were applied separately, the populations of all four declined sharply by day three. The populations of $T$. harzianum T39 on treated cucumber leaves were 70,55 

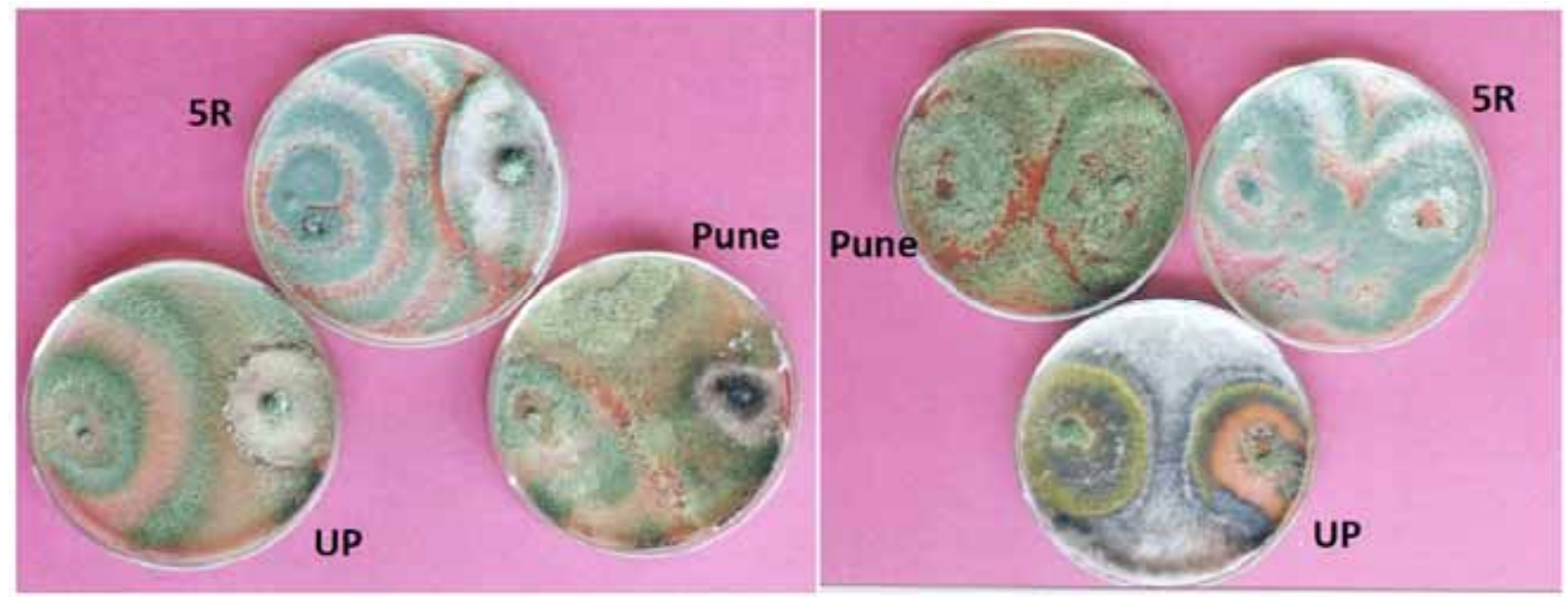

Fig. (15). Overgrowth of three isolates of Trichoderma on (a) Alternaria alternata and (b) Botryodiplodia theobromae. Note isolate 5R has overgrown both the fungi, while Pune isolate has overgrown B. theobromae but not A. alternata, while UP isolate has overgrown A. alternata but not $B$. theobromae.

and $50 \mathrm{cfu} / \mathrm{cm}^{2}$ of leaf after 0,2 and 6 days of application at rate of $0.2 \%$ of formulation containing $10^{9} \mathrm{cfu} / \mathrm{g}$ [15].

On the contrary, the isolate $T$. atroviride C65 applied as foliar spray at bud burst could survive on leaves and flowers/fruits of kiwi fruits up till harvest, a period of more than 3 months [59]. It also spread to unsprayed leaves and fruits upto $3 \mathrm{~m}$ away, dispersed either by insects or by wind currents.

\section{ISOLATE VARIATIONS}

Different Trichoderma species are reported as antagonists of a particular pathogen species, eg. all the 34 isolates belonging to seven Trichoderma species could cause lysis of C. gloeosporioides mycelium (Fig. 14); but variations among isolates from the same species were reported [26]. Variation in antagonism of any one isolate to different pathogen species are also observed, e.g. three Trichoderma isolates viz. 5R, Pune and UP when tested against two pathogens of grapes, isolate $5 \mathrm{R}$ overgrew and lysed mycelium of both pathogens, while Pune isolate has overgrown and lysed $B$. theobromae but not $A$. alternata, and UP isolate has overgrown and lysed A. alternata but not $B$. theobromae (Fig. 15). Thus systematic search for isolates with wide host range is essential when dealing with crops where more than one pathogen needs to be controlled simultaneously. One study has shown that isolates belonging to the taxonomic section Trichoderma sect. Pachybasium produce chemicals inhibitory to fungi and bacteria, while isolates belonging to $T$. sect. Longibrachiatum were more inhibitory to yeasts [60]. This kind of information can guide search for potential antagonistic isolates.

\section{FUTURE CHALLENGES}

Commercialization of the selected efficient isolates is the biggest challenge. The large numbers of research laboratories around the world have, through their painstaking research, identified a number of isolates which can be successfully utilized for control of a specific disease on a target crop in that particular geographical area. In most cases, these isolates have not been tested for their efficiency of, i) disease control under different agro-climatic conditions and over a number of years, ii) the same pathogen on different crops cultivated under different agroecosystems; iii) control of multiple disease on the same crop; iv) integration with fungicides etc. This has resulted in a large number of isolates which, though, highly efficient under the experimental conditions, may be limited in their use on a commercial scale. Inter-institutional collaborations for wide scale evaluation of these isolates is the immediate need for identifying isolates with wide applicability. The most efficient isolate(s) can be developed into commercial products which will overcome many of the issues associated with small scale production.

\section{CONFLICT OF INTEREST}

The authors confirm that this article content has no conflicts of interest.

\section{ACKNOWLEDGEMENTS}

Declared none.

\section{REFERENCES}

[1] Samuels GJ. Trichoderma: Systematics, the sexual state, and ecology. Phytopathol 2006; 96:195-206.

[2] Lindow SE, Brandl MT. Microbiology of the Phyllosphere. Appl Environ Microbiol 2003; 69: 1875-83.

[3] Trichoderma harzianum Rifai strain T-39 (119200) Technical Document. Available from: http://www.epa.gov/pesticides/chem_search/reg_actions/registration/related_ PC-119200_1-May00.pdf

[4] Novel isolate of Trichoderma harzianum, T-39, fungicidal compositions containing said isolate and use against $B$. cinerea and S. sclerotiorum. Available from: http://www.google.com/patents/EP0466133A2

[5] Rajkovic S, Markovic M, Rajkovic R, Rakonjac L. Biofungicide Trichodex WP. World Acad Sci Eng Tech 2013; 78: 1703-7. Available from: http://www.waset.org/journals/waset/v78/v78294.pdf 
[6] O' Neill TM, Elad Y, Shtienberg D, Cohen A. Control of grapevine grey mould with Trichoderma harzianum T39. Biocontrol Sci Techn 1996; 6: 139-46.

[7] Elad Y. Biological control of grape grey mold by Trichoderma harzianum. Crop Prot 1994; 13: 35-8.

[8] Harman GE, Latorre B, Agosin E, et al. Biological and integrated control of Botrytis bunch rot of grape using Trichoderma spp. Biol Control 1996; 7: 259-66.

[9] Kohl J, Schlosser E. Decay of sclerotia of Botrytis cinerea by Trichoderma spp. at low temperatures. J Phytopathol 1988; 125: 320-6

[10] Trosmo A, Dennis C. The use of Trichoderma species to control strawberry fruit rots. Neth J Plant Pathol 1977; 83: 449-55.

[11] Freeman S, Minz D, Kolesnik I, et al. Trichoderma biocontrol of Colletotrichum acutatum and Botrytis cinerea and survival in strawberry. Eur J Plant Pathol 2004; 110: 361-70.

[12] Kovach K, Petzoldt R, Harman GE. Use of honey bees and bumble bees to disseminate Trichoderma harzianum 1295-22 to strawberries for Botrytis control. Biol Control 2000; 18: 235-42.

[13] Shafir S, Dag A, Bilu A, Abu-Toamy M, Elad Y. Honey bee dispersal of the biocontrol agent Trichoderma harzianum T39: effectiveness in suppressing Botrytis cinerea on strawberry under field conditions. Eur J Plant Pathol 2006; 116: 119-28.

[14] Elad Y. Trichoderma harzianum T39 preparation for biocontrol of plant diseases- control of Botrytis cinerea, Sclerotinia sclerotiorum and Cladosporium fulvum. Biocontrol Sci Tech 2000; 10: 499-507.

[15] Elad Y, Kirshner B, Yehuda N, Sztejnberg A. Management of powdery mildew and gray mold of cucumber by Trichoderma harzianum T39 and Ampelomyces quisqualis AQ10. Biocontrol 1998; 43: 241-51.

[16] Mmbaga MT, Sauvé RJ, Mrema FA. Identification of microorganisms for biological control of powdery mildew in Cornus florida. Biol Control 2008; 44: 67-72.

[17] Deore PB, Sawant DM, Ilhe BM. Comparative efficacy of Trichoderma spp. for the control of powdery mildew of cluster bean. Indian J Agric Res 2004; 38: 212-6.

[18] Raja SA. Management of powdery mildew, Phyllactinia corylea (Pers.) Karst of Mulberry (Morus sp.) using chosen biocontrol agents. J Biopest 2010; 3: 483-6.

[19] Elkot GAE, Derbalah ASH. Use of cultural filtrates of certain microbial isolates for powdery mildew control in squash. J Plant Prot Res 2011; 51: 252-60.

[20] Perazzolli M, Dagostin S, Ferrari A, Elad Y, Ilaria P. Induction of systemic resistance against Plasmopara viticola in grapevines by Trichoderma harzianum T39 and benzothiadiazole. Biol Control 2008; 47: 228-34.

[21] Perazzolli M, Moretto M, Fontana P, et al. Downy mildew resistance induced by Trichoderma harzianum T39 in susceptible grapevines partially mimics transcriptional changes of resistant genotypes. BMC Genomics 2012; 13: 660.

[22] Shovan LR, Bhuiyan MKA, Begum JA, Pervez Z. In vitro control of Colletotrichum dematium causing anthracnose of soybean by fungicides, plant extracts and Trichoderma harzianum. Int J Sustain Crop Prod 2008; 3: 10-7.

[23] Sobowale AA, Odeyingbo OA, Egberongbe HO, Feyisola RT, Ayinde OA, Adesemowo A. Growth inhibition (in vitro) of Colletotrichum gloeosporioides isolated from cassava (Manihot esculenta) using Trichoderma longibrachiatum. Afr J Microbiol Res 2010; 4: 2196-201.

[24] Sivakumar D, Wijeratnam RSW, Wijesundera RLC, Marikar FMT, Abeyesekere M. Antagonistic effect of Trichoderma harzianum on postharvest pathogens of Rambutan (Nephelium lappaceum). Phytoparasitica 2000; 28: 240-7.

[25] Soytong K, Srinon W, Rattanacherdchai K, Kanokmedhakul S, Kanokmedhakul K. Application of antagonistic fungi to control anthracnose disease of grape. J Agric Biotechnol 2005; 1: 33-41.

[26] Sawant IS, Rajguru YR, Salunkhe VP, Wadkar PN. Identification of efficient Trichoderma species and isolates from diverse locations in India for biological control of anthracnose disease of grapes. J Biol Control 2012; 26: 144-54.

[27] Tondje PR, Roberts DP, Bon MC, et al. Isolation and identification of mycoparasitic isolates of Trichoderma asperellum with potential for suppression of black pod disease of cacao in Cameroon. Biol Control 2007; 43: 202-12.
[28] Barbosa MAG, Rehn KG, Menezes M, Mariano RLM. Antagonism of Trichoderma species on Cladosporium herbarum and their enzimatic characterization. Braz J Microbiol 2001; 32: 98-104.

[29] Sawant SD, Sawant IS. Improving shelf life of grapes by preharvest treatment with Trichoderma harzianum 5R. J Eco-Friendly Agric 2010; 5: 179-82

[30] Sawant IS, Sawant SD. Integration of Trichoderma harzianum 5R with low dose of sulphur dioxide generator sheet for control of postharvest decay of Tas-A-Ganesh (Vitis vinifera L.) during and after long duration low temperature storage. J Eco-Friendly Agric 2011; 6: 180-6.

[31] Sivakumar D, Wijeratnam RSW. Antagonistic effect of Trichoderma harzianum on postharvest pathogens of rambutan (Nephelium lappaceum). Phytoparasitica 2000; 28: 240-7.

[32] Wijesinghe CJ, Wijeratnam RSW, Samarasekara JKRR, Wijesundera RLC. Biological control of Thielaviopsis paradoxa on pineapple by an isolate of Trichoderma asperellum. Biol Control 2010; 53: 285-90.

[33] Batta YA. Control of postharvest diseases of fruit with an invert emulsion formulation of Trichoderma harzianum Rifai Postharvest Biol Technol 2007; 43: 143-50.

[34] Hoitink HAJ, Madden LV, Dorrance AE. Systemic resistance induced by Trichoderma spp.: interactions between the host, the pathogen, the biocontrol agent, and soil organic matter quality. Phytopathol 2006; 96: 186-9.

[35] Elad Y, David DR, Levi T, Kapat A, Kirshner B. In: Lyr H, Russell PE, Dehne HW, Sisler HD, Eds. Modern fungicides and antifungal compounds II. Andover, Intercept Limited, 1999; 459-67.

[36] Verma M, Brar SK, Tyagi RD, Surampalli RY, Valero JR. Antagonistic fungi, Trichoderma spp.: panoply of biological control. Biochem Eng J 2007; 37: 1-20.

[37] Marco JL, Valadares-Inglis MC, Felix CR. Production of hydrolytic enzymes by Trichoderma isolates with antagonistic activity against Crinipellis perniciosa, the causal agent of witches' broom of cocoa. Braz J Microbiol 2003; 34: 33-8.

[38] Marco JL De, Felix CR. Characterization of a protease produced by a Trichoderma harzianum isolate which controls cocoa plant witches' broom disease. BMC Biochem 2002; 3: doi:10.1186/14712091-3-3.

[39] Elad Y, Stewart A. In: Elad Y, Williamson B, Tudzynski P, Delan N, Ed. Botrytis: Biology, Pathology and Control. Dordrecht, Kluwer Academic 2004; 223-41.

[40] Ajith PS, Lakshmidevi N. Effect of volatile and non-volatile compounds from Trichoderma spp. against Colletotrichum capsici incitant of anthracnose on bell peppers. Nature Sci 2010, 8: 265-9.

[41] Faheem A, Razdannn VK, Mohiddin FA, Bhat KA, Sheikh PA. Effect of volatile metabolites of Trichoderma species against seven fungal plant pathogens in vitro. J Phytopathol 2010; 2: 34-7.

[42] Elad Y, Kapat A. The role of Trichoderma harzianum protease in the biocontrol of Botrytis cinerea. Eur J Plant Pathol 1999; 105: 177-89.

[43] Kapat A, Zimand G, Elad Y. Effect of two isolates of Trichoderma harzianum on the activity of hydrolytic enzymes produced by Botrytis cinerea. Physiol Mol Plant Pathol 1998; 52:127-37.

[44] Zimand G, Elad Y, Chet I. Effect of Trichoderma harzianum on Botrytis cinerea pathogenicity. Phytopathol 1996; 86: 1255-60.

[45] Roco A, Pérez LM. In vitro biocontrol activity of Trichoderma harzianum on Alternaria alternata in the presence of growth regulators. Electron J Biotechnol 2001; 4: 68-73.

[46] Lorito M, Harman GE, Hayes CK, et al. Chitinolytic enzymes produced by Trichoderma harzianum: antifungal activity of purified endochitinase and chitobiosidase. Phytopathol 1993; 83: 302-7.

[47] Peng G, Sutton JC. Evaluation of microorganisms for biocontrol of Botrytis cinerea in strawberry. Can J Plant Pathol 1991; 13: 24757.

[48] Perazzolli M, Roatti B, Bozza E, Pertot I. Trichoderma harzianum T39 induces resistance against downy mildew by priming for defense without costs for grapevine. Biol Control 2011; 58: 74-82.

[49] Horst LE, Locke J, Krause CR, McMahon RW, Madden LV, Hoitink HAJ. Suppression of Botrytis blight of begonia by Trichoderma hamatum 382 in peat and compost-amended potting mixes. Plant Dis 2005; 89:1195-200.

[50] Khan J, Ooka JJ, Miller SA, Madden LV, Hoitink HAJ. Systemic resistance induced by Trichoderma hamatum 382 in cucumber 
against Phytophthora crown rot and leaf blight. Plant Dis 2004; 88: 280-6.

[51] Yedidia I, Benhamou N, Chet I. Induction of defense responses in cucumber plants (Cucumis sativus L.) by the biocontrol agent Trichoderma harzianum. Appl Environ Microbiol 1999; 65: 106170.

[52] Hjeljord L, Tronsmo A. In: Harman GE, Kubicek CP, Eds. Trichoderma and Gliocladium. Vol. 2. Enzymes, Biological Control and Commercial Applications. London: Taylor and Francis Ltd.; 1998; 131-51.

[53] Grosclaude C, Ricard J, Dubos B. Inoculation of Trichoderma viride spores via pruning shears for biological control of Stereum purpureum on plum tree wounds. Plant Dis Rep 1973; 57: 25-8.

[54] Lorito M, Peterbauer C, Hayes CK, Harman GE. Synergistic interaction between fungal cell wall degrading enzymes and different antifungal compounds enhances inhibition of spore germination. Microbiology 1994; 140: 623-9.

[55] Narkar SP, Shetty DS, Sawant IS, Sawant SD. Paradigm shift in the resistance of grape isolates of Colletotrichum gloeosporioides to carbendazim and their bio-control by Trichoderma harzianum. Indian Phytopathol 2012; 65: 373-7.

[56] Elad Y, Kirshner B. Survival in the phylloplane of an introduced biocontrol agent (Trichoderma harzianum) and populations of the plant pathogen Botrytis cinerea as modified by abiotic conditions. Phytoparasitica 1993; 21: 303-13.

[57] Elad Y, Kirshner B. Establishment of an active Trichoderma population in the phylloplane and its effect on grey mold (Botrytis cinerea). Phytoparasitica 1992; 20: 137-41.

[58] Freeman S, Minz D, Kolesnik I, et al. Trichoderma biocontrol of Colletotrichum acutatum and Botrytis cinerea and survival in strawberry. Eur J Plant Pathol 2004; 110: 361-70.

[59] Dodd SL, Hill RA, Stewart A. Monitoring the survival and spread of the biocontrol fungus Trichoderma atroviride (C65) on kiwifruit using a molecular marker. Australas Plant Pathol 2004; 33: 189-96.

[60] Vizcaíno JA, Sanz L, Basilio A, et al. Screening of antimicrobial activities in Trichoderma isolates representing three Trichoderma sections. Mycol Res 2005; 109:1397-406.

(C) Indu S Sawant; Licensee Bentham Open.

This is an open access article licensed under the terms of the Creative Commons Attribution Non-Commercial License (http://creativecommons.org/ licenses/by-nc/3.0/), which permits unrestricted, non-commercial use, distribution and reproduction in any medium, provided the work is properly cited. 